\title{
The Relationship between Blood Circulation and Exercise Headache before and after the Publication of De Motu Cordis (1628): Comparison between the Scientific Thought of Girolamo Mercuriale (1530-1606) and Bernardino Ramazzini (1633-1714)
}

\author{
Emanuele Armocida \\ Department of Medicine and Surgery, University of Parma, Parma, Italy
}

\section{Keywords}

History of neurology - Blood circulation - Exercise

headache · Girolamo Mercuriale · Bernardino Ramazzini

\begin{abstract}
The relationship between physical activity, sports and headache is a topic of growing interest as testified by a variety of recently published papers. This correlation dates back to the Classical Age. The aim of this study is to understand how the concept of headache of vascular origin has evolved after the publication of the book De motu cordis by William Harvey (1578-1657). We analyzed and compared the books De arte gymnastica written by Girolamo Mercuriale (1601 edition) and De Morbis Artificum Diatriba written by Bernardino Ramazzini (1713 edition) focusing our attention on headache in the sportsman. By studying the De morbis artificum diatriba, it is clear that its description of the etiopathogenesis of exercise headache of cardiovascular origin is much more complete and precise than the one provided in De arte gymnastica. The limits of scientific knowledge of his time put Mercuriale at disadvantage, since cardiovascular physiology was not elucidated until 1628 with the publication of De motu cordis.

(c) 2019 S. Karger AG, Basel
\end{abstract}

(c) 2019 S. Karger AG, Basel

karger@karger.com

www.karger.com/ene

\section{Introduction}

The relationship between physical activity, sports and headache is a topic of growing interest as testified by a variety of recently published papers [1]. This correlation dates back to the classical age. Terrin et al. [2] gave an accurate historical description of this condition analyzing the first sports textbook, De arte gymnastica, written by Girolamo Mercuriale (1530-1606).

Mercuriale was born in the city of Forli; he was educated at Bologna, Padua and Venice, where he received his doctorate in 1555 . He studied the classical and medical literature of the Greeks and Romans. His studies of the attitudes of the ancients toward diet, exercise, and hygiene and the use of natural methods for the cure of diseases culminated in the publication of his De Arte Gymnastica [3].

The treatise appeared in the first draft in Venice in 1569, with a dedication to Cardinal Alessandro Farnese. A subsequent reprint was published in the years 15691573, expanded and modified with the title of De arte gymnastica libri VI, in quibus exercitationum omnium vatustarum generates, loca, mondi, facultates et quidquid denique ad corporis humani exercitationes pertinet diligenter 
explicantur, with dedication to Emperor Maximilian II. These were followed by further editions (Paris 1577, Venice 1587 and Venice 1601), published while the author was still alive [2].

The book De Arte Gymnastica brought Mercuriale fame. He was called to occupy the chair of practical medicine in Padua in 1569. He wrote many other important books: De morbis cutaneis (1572), which is considered the first scientific treatise on skin diseases; De morbis muliebribus ("On the diseases of women"; 1582); De morbis puerorum ("On the diseases of children"; 1583), which is considered by some historians the first pediatric treatise; De oculorum et aurium affectibus ("The eyes and ears and emotions"); and Censura e dispositio operum Hippocratis (Venice, 1583).

After leaving Padua, he taught at the Universities of Bologna and Pisa before dying in Forlì in 1606 [3].

According to Terrin et al. [2], Mercuriale attributed the origin of exercise headaches to a number of causes, including hindered blood outflow from the head, secondary to an increase of the intrathoracic pressure or to a Valsalva maneuver producing intracranial hypertension. This alteration was thought to cause the stretching of the vessel walls of venous sinuses and, consequently, pain.

From a careful analysis of the book it is possible to point out that Mercuriale was very accurate in describing the causes and symptoms of headache, but he was very inaccurate in the description of etiology of headache of vascular origin.

Symptoms similar to those presented by patients with hypertensive crisis were discussed in medieval Persian medical texts as "fullness disease." The symptoms included headache, heaviness in the head, vascular rupture, and hemorrhagic stroke. Fullness disease was presumed to be due to an excessive amount of blood within the blood vessels, and Mercuriale seemed to support this theory, as he used a terminology typical of humoral theories.

On the other hand, Mercuriale could only use the physiology knowledge available at his time.

As a matter of fact, modern understanding of the cardiovascular system began only with the work of the physician William Harvey (1578-1657), who described blood circulation in his book De motu cordis. Later, the English clergyman Stephen Hales (1677-1761) made the first direct measurement of blood pressure in 1733 . The earliest (1808) description of hypertension as a disease is attributed to Thomas Young (1773-1829). However, hypertension as a clinical entity was definitely established only with the invention of the cuff-based sphygmomanometer by Scipione Riva-Rocci (1863-1937) in 1896 [4].

The Relationship between Blood

Circulation and Exercise Headache
After Mercuriale, a number of observations on the effects of gymnastics on the human organism were published, often made by Italian scholars, such as Bernardino Ramazzini (1633-1714).

Bernardino Ramazzini was born in Carpi, Italy, in 1633. After his medical graduation in 1659 in Parma, he started to work as physician in Rome and in the Duchy of Castro, a vassal state to the Papal States. He was forced to leave Rome and return to his hometown because of a severe malarial infection he contracted. In 1682, he was appointed as Professor of Theoretical Medicine at the University of Modena by the Duke Francesco II d'Este (1660-1694). During this period, he wrote several medical works, especially focused on population studies. Ramazzini first described the artesian aquifers, made observations on natural history, and conducted studies on the influence of atmospheric agents during the course of epidemic diseases. In regards to malaria, Ramazzini was one of the first to support the use of the quinine-rich bark cinchona. He was very familiar with the ancient Greek and Roman medical authors but also with coeval physicians and intellectuals. Ramazzini is often considered "the father of occupational health" because at the end of the seventeenth century, he started to investigate the influence of occupations on workers' health, teaching a class on this subject at the University of Modena [5].

In 1700, in Modena, Ramazzini published the first edition of De Morbis Artificum Diatriba (Diseases of Workers), reedited in 1713 in Padua. His treatise on occupational diseases outlined the health hazards of chemicals, dust, metals, repetitive or violent motions, odd postures, and other disease-causative agents encountered by workers in 69 occupations.

Ramazzini's studies gave an important contribution to the development of neurology. He can be considered a pioneer of neurotoxicology because he acknowledged that the exposure to toxic metals can cause both physical and behavioral alterations. In chapter VII ("Diseases of glass-workers and mirror-makers") of his masterpiece, Ramazzini described the effects of mercury on motor function and mood. Furthermore, in chapter IX, he explained that painters were afflicted by palsy of the limbs, caused by colors of mineral origin containing pigments of mercury, lead and copper [5].

Regarding the headache, it is quoted in 15 instances in De Morbis Artificum Diatriba, 12 of which as a disturbance directly related to working conditions. The main categories involved, according to Ramazzini, were pharmacists, carpenters, brewers, tobacco workers and oil producers, confectioners, desk workers and stenographers, Jewish women, lackeys and runners, hunters and 
sailors, wetnurses, those working with wine and beer, sewer cleaners, musicians and singers, and soldiers [6]. His remarks on headache were typical of his way of collecting first-hand experience of working conditions, and they underlined the importance of occupational hazards in the assessment of headache. Ramazzini was really interested in headache and its different aspects. Reading his description of his own reaction to bad smells in grimy shops, we may infer that he himself suffered from migraine. Ramazzini introduced the concept of osmophobia, which he referred in more than a single passage to the relation between olfactory stimulus and headache's onset ("capitis dolor"), particularly dealing with the illnesses of pharmacists, brewers, tobacco workers, oil producers, and carpenters [7].

Less known is that some historians also consider him one of the "fathers" of sports medicine [8].

Indeed the pathologies of runners, jockeys and wrestlers were also taken into consideration by Ramazzini in his systematic study of occupational diseases.

Moreover, in the text, the Italian physician often indicated the importance of physical activity, especially among sedentary workers. Ramazzini further developed these concepts in another treatise - De Principum valetudine tuenda commentatio ("The health of princes," 1710) - in which he suggested that princes should safeguard their health throughout "frugal and simple nourishment" and "daily physical exercise" [9].

\section{Methods}

Here we analyze the book De Morbis Artificum Diatriba focusing our attention on sport-related headache and comparing it to the studies of Mercuriale [10]. The aim is to understand how the concept of headache of vascular origin had evolved after the publication of the book De motu cordis. We considered the 1713 edition of the textbook, the most complete of those published during the life of the author [11], written in Latin and translated into English by us.

\section{Results}

As far as horse riding is concerned (De morbis equisonum), Ramazzini makes no explicit reference to the headache caused by this practice, and therefore, the comparison with Mercuriale is not possible (11, p. 185-190).

As regards to wrestling, Mercuriale described its advantages and disadvantages (De luctae commoditatibus et incommoditati- bus) and reported: "wrestling has the particular effect of being useful against head pains, especially if performed with an umpire, in an equally matched contest, as recommended by Caelius Aurelianus" (10, p. 245). On the contrary, "...if we believe Oribasius... wrestling on the floor is less suitable for the head" (10, p. 246).

In the chapter De athletarum morbis, Ramazzini described the diseases of the wrestlers. He did not mention headaches but described other cerebrovascular disorders that are worth mentioning:

"Apoplexy, heart syncope, suffocating catarrhs, rupture of blood vessels in the chest, sudden deaths. The cause of this infirmity was mainly a superset of humors (humorum plenitudo), and the distension of the vessels, so much so that the motion of the blood was notably delayed or completely impeded (ut sanguinis motus vel insigniter retardaretur, vel prorsus tolleretur). The blood is intercepted (hinc venarum interceptions), to use the phrase of Hippocrates, that is to say, there is a stagnation of the blood, and a concentration of all the fluids (fluidorum omnium), so that sudden death was following by necessity" (11, p. 196).

"...in a vigorous exercise the mass of the blood heats up a lot (valdè incalescit), and it is rarefied (rarescit) so that the blood cannot flow from the arteries into the veins (ab arteriis in venas) with the due promptness, or soon it can return for the veins, as it goes, and it flows through the arteries, and much less when there is a fullness of vessels" (11, p. 196).

In the chapter De cursus natura Mercuriale wrote about the runners:

"Running is particularly harmful to people suffering from any condition of the head. Aristoteles moves from the general opinion that a fast run draws every kind of residue downwards. Looking for the reasons why running, it can provoke headache in humans as in animals. He states that, if it is fast it intensifies the strength and inhibits the breath heats the head up and greatly distends its veins, making them receptive to any external influence, such as cold and heat: it forces the contents of the chest to rise upwards. All these factors necessarily provoke illness in the upper parts" (10, p. 250). Further, in the same chapter: "The same author (Aristoteles) assures that running cools the flesh and lowers its availability of nutritional substances, as part of the food is passed downwards, while another part is dissolved as natural heat and is converted into spirit. Nor does this kind of exercise, of its own nature, produce any damage worth mentioning. If the patient is weak and fragile in his head or his chest, or affected by a disease causing frequent minges, running can be surely responsible of many diseases. That is what the author of the fourth book Diet in acute diseases means by saying that some people suffer from headache because of the running. Cassius the Iatrosophist confirms this idea in clearer terms... in his Medical Problems. He wonders why people suffering from headache use to feel relief after a moderate movement, while people not affected by any pain or heaviness of their head, may suffer from headache during or at the end of a run. Here is his answer: during slow movements, materials accumulate towards the lower parts of the body, where they are confirmed in their position. Instead, with 
running, the fluids may indeed go down towards the lower parts of the body but, as soon as they arrive, they promptly rebound upwards, just like a ball bounced on the floor. If it is dropped gently, it remains still; if hurled with violence, it immediately rebounds" (10, p. 251).

In the chapter De cursorum morbis, Ramazzini openly urged readers to ignore Lodovico Settala (1550-1633), Giulio Gustavino (-1633) and the previous authors who had investigated the subject (he did not explicitly cite Mercuriale). Ramazzini claimed that the real cause of the headache was the following:

"In the fast running the vesicles of the lung are overinflated, and the blood flowing back through the vena cava above the heart is checked in its course, so to speak, so that it cannot flow freely into the vassels of lung; hence of necessity it stagnates in the head (ac reduci sanguini per venam cavam supra cor veluti remora injiciatur, ne tam libere in vasa pneumonica influat, ex quo fiat, ut in capite necessario restagnent), and causes serious diseases. This which does not happen in a moderate run, which actually helps to move the humors from the bottom" (11, p. 182).

\section{Discussion}

From the analysis of the texts it is clear that the interpretation provided by Ramazzini of the neurological disorders that occur during exercise is more accurate and scientifically advanced than the one presented by Mercuriale.

Mercuriale described the headache related to the practice of wrestling, but he is unable to explain what the cause is. Indeed Mercuriale cited classical authors without defining a specific etiopathological cause of headache in wrestlers.

Ramazzini did not describe directly the headache in wrestlers, but identified a prevalence of neurological disorders with cardiovascular etiopathogenesis, such as syncope and apoplexy. In this case, Ramazzini mixed the principles of hemodynamics and terminology typical of the humoral theory, explicitly quoting Hippocrates, testifying to the moment of transition between traditional Hippocratic medicine and the new experimental sciences.

That said, to clearly understand how the classification of exercise headaches changed after the discovery of circulation, we have to compare the chapters devoted by Mercuriale and Ramazzini to pathologies affecting runners.

Mercuriale relied on Aristotles' observations on the fast run to describe the physiological phenomena that oc- cur in runners: "if it is fast it intensifies the strength and inhibits the breath, it heats the head up and greatly distends its veins, making them receptive to any external influence, such as cold and heat: it forces the contents of the chest to rise upwards."

These words seem to describe a Valsalva maneuver; however, on these uncertain bases, Mercuriale is forced to formulate more or less fanciful theories to describe the headache in the runner.

Ramazzini described the circulatory phenomena behind the origin of the headache in extremely modern anatomical and physiological terms.

\section{Conclusion}

Bernardino Ramazzini, although still tied to Hippocratic medicine, used a modern scientific thought as a consequence of experimental medicine.

It is likely that he was the first to understand the etiopathogenesis of the exercise headache of cardiovascular origin.

When studying Ramazzini's De morbis artificum diatriba, 1713, it is clear that his description is much more complete and precise than the one provided in De arte gymnastica, written by Girolamo Mercuriale, published in 1601.

Mercuriale paid for the limits of scientific knowledge of his time, since cardiovascular physiology began to be elucidated only in 1628 with the publication of De motu cordis by William Harvey.

\section{Acknowledgment}

The author wishes to thank Professor Ovdio Bussolati for his collaboration and support.

\section{Statement of Ethics}

The authors have no ethical conflicts to declare.

\section{Disclosure Statement}

The author declares no conflict of interest.

\section{Funding Sources}

The author declares that no funds have been received. 


\section{References}

1 Ramadan NM. Sports-related headache. Curr Pain Headache Rep. 2004 Aug; 8(4): 301-5.

2 Terrin A, Mainardi F, Zanchin G, Maggioni F. Sports, physical activity and headache in the classical age: historical descriptions from the first sports textbook, "De arte gymnastica”, by Girolamo Mercuriale. Neurol Sci. 2019 Jul;40(7):1507-17.

3 Peltier LF. The classic. Geronimo Mercuriali (1530-1606) and the first illustrated book on sports medicine. Clin Orthop Relat Res. 1985 Sep;(198):21-4.
4 Heydari M, Dalfardi B, Golzari SE, Habibi H, Zarshenas MM. The medieval origins of the concept of hypertension. Heart Views. 2014 Jul;15(3):96-8.

5 Riva MA, Belingheri M, De Vito G, Lucchini R. Bernardino Ramazzini (1633-1714). J Neurol. 2018 Sep;265(9):2164-5.

6 Zanchin G, Rossi P, Isler H, Maggioni F. Headacheas an occupationalillness in the treatise "De morbis artificum diatriba" of Bernardino Ramazzini. Cephalalgia.1996Apr;16(2):79-86.

7 Zanchin G. Padua, the cradle of modern medicine: bernardino Ramazzini (1633-1714) on headaches. J Headache Pain. 2005 Sep;6(4): 169-71.

8 Buchanan WW. Bernardino Ramazzini (1633-1714) physician of tradesmen, and possibly one of the "fathers" of sports medicine. Clin Rheumatol. 1991 Jun;10(2):136-7.

9 Riva MA, Belingheri M. Bernardino Ramazzi$\mathrm{ni}$ in the fourth industrial revolution. Am J Ind Med. 2019 Jul;62(7):631-2.

10 Mercurialis H. De arte gymnastica. Venice: Apud Iuntas; 1601. pp. 55-307.

11 Ramazzini B. De morbis artificum diatriba. Venice: apud J. Corona; 1743. 